\title{
Prediction of shoreline change using a numerical model: case of the Kulon Progo Coast, Central Java
}

\author{
Asrini Chrysanti ${ }^{1,2, *}$, Mohammad Bagus Adityawan ${ }^{1,2,3}$, Widyaningtyas ${ }^{1,2}$, Bagus Pramono Yakti ${ }^{1}$, Joko Nugroho ${ }^{1,3}$, \\ Khilmi Zain ${ }^{4}$, Iman Haryanto ${ }^{4}$, Muhammad Sulaiman ${ }^{4}$, Adhy Kurniawan ${ }^{4}$, and Hitoshi Tanaka ${ }^{5}$ \\ ${ }^{1}$ Water Resources Engineering Research Group, Faculty of Civil and Environmental Engineering, Institut Teknologi Bandung, \\ Bandung, Indonesia \\ ${ }^{2}$ Center for Coastal and Marine Development, Institute for Research and Community Services, Institut Teknologi Bandung, Bandung, \\ Indonesia \\ ${ }^{3}$ Center for Water Resources Development, Institute for Research and Community Services, Institut Teknologi Bandung, Bandung, \\ Indonesia \\ ${ }^{4}$ Civil and Environmental Engineering Department, Faculty of Engineering, Universitas Gadjah Mada, Yogyakarta, Indonesia \\ ${ }^{5}$ Civil and Environmental Engineering Department, Faculty of Engineering, Tohoku University, Sendai, Japan
}

\begin{abstract}
Kulon Progo Airport is an airport development project located in the coastal area near Yogyakarta, Indonesia, which is expected to complete in 2019. With the increase in population, huge land acquisition will be difficult, so the development of coastal areas for the airport became inevitable. Kulon Progo is located in the disaster-prone zone area of the earthquake and tsunami, the airport design must consider the risk management and mitigation from tsunami and earthquake disaster. Although the airport is already calculated the danger of earthquake and tsunami, the development of the coastal area also needs to consider the danger of the natural coastal process itself such as sedimentation and erosion. Shoreline changes due to the new infrastructure in the coastal area can disrupt the equilibrium of coastal process especially the longshore sediment transport. A satellite image shows that Kulon Progo shoreline retreats over 60 meters due to the heavy sediment longshore transport in the past 10 years. Breakwaters in Tanjung Adikarto fishing port also made a great contribution in huge sedimentation behind the infrastructure up to 90 meters. This research will conduct an analysis trough satellite and numerical model to observe the shoreline changes along Kulon Progo Coast. A numerical model shows a high erosion rate along the coast. High sedimentation also observed at the river mouth of Bogowonto and Serang Rivers.
\end{abstract}

\section{Introduction}

Indonesia as an archipelago has great potentials in developing coastal areas. The development of coastal areas is currently being carried out intensively by the government. The country has been building numerous infrastructures to support the Indonesian economy, such as airports. The development of airport infrastructure in coastal areas certainly has a high risk of being affected by disasters such as tsunamis and high waves. According to IRiDES (International Research Institute of Disaster Science), there are sixteen airports in Indonesia that were built in tsunami-vulnerable zones and did not show any disaster risk reduction efforts.

The earthquake and tsunami that occurred in December 2004 caused destruction to infrastructures in Aceh coast. Disaster hazards in coastal areas other than tsunamis such as storms and floods are also very dominant in Indonesia, especially for areas where the land elevation is lower than the sea level. The southern region of
Indonesia is a very dominant area for the tsunami disaster. The high risk of disasters in coastal areas certainly requires special studies in disaster risk reduction efforts in coastal areas.

The government is currently building a new international airport in Kulon Progo, the southern part of Central Java. The southern Java supporting zone in the Java-Bali segment triggered a major earthquake in the 1980s. The potential natural disasters in Kulon Progo Regency were earthquakes and tsunamis. The new airport development will greatly enhance the development of the surrounding coastal area. Hazard mitigation in this area is important. Strategies for managing disaster-prone zones can be done by controlling permanent and semipermanent buildings in disaster-prone zones.

One of the risks that the area is facing is shoreline changes. Shoreline changes can be caused by a sudden event such as a tsunami [1-4] and also due to the natural processes of wave and current interactions [5-8]. Strong parallel currents of the coast may induce erosion as

\footnotetext{
* Corresponding author: asrinichr@gmail.com
} 
happened at Balongan, Indramayu, West Java. High erosion occurred along the Indramayu Coast. The previous study stated that Balongan coast erosion rate was $29.38 \mathrm{Ha}$ /year, with 6 kilo meters long of Balongan Coast the erosion rate estimated occurred 5 meters/year [9].

Planning for inappropriate coastal protection buildings will also disrupt the balance of the coast, so that it can exacerbate existing problems. I Gusti Ngurahrai Airport in Bali is an example of shoreline changes that occur due to coastal infrastructure development that disrupts the balance of the coast. Shoreline coast continuously modified by natural and other man-made processes.

The shoreline is one of the most unique features of earth surface [10]. A shoreline is defined as the line of contact between land and water body. It is easy to define but difficult to capture since it is always changing. Accurate demarcation and monitoring of shorelines (seasonal, short-term and long-term) are necessary for understanding various coastal processes [11]. Therefore, the present study using remote sensing and GIS will be very useful to assess the impact of hydrological and morphologic factors modifying the shorelines along this area.

Several studies have been conducted to analyze the shoreline changes especially due the extreme condition such as tsunamis. Tsunamis had significant impact to the coastal area, and cause the morphology to became unstable. Coastal morphology will achieve the new equilibrium condition after some period of time and often different from before tsunami condition and sometimes causing problem to the river mouth. Several studies in Japan shows valuable information for restoration process and future disaster prevention from morphological changes by aerial photo studies $[1,2,3,4]$.

Determination of strategies in protection and development needs to be comprehensively studied, by simulating several disaster scenarios that might occur in coastal areas, analysing impacts so that they will produce planning recommendations for disaster risk. The purpose of this study is to determine appropriate strategies to reduce disaster risk in coastal areas with the concept of good protection and development for infrastructure in coastal areas. Protection and development is not limited to determining coastal protection structures (breakwaters, dikes, etc.), but also by determining the concept of layout planning and determining good management in dealing with disasters and problems on the coast.

\section{Study area}

The study area of this research is the Kulon Progo Coast, Central Java. This area is planned to develop a new airport area which expected to be complete in 2019. Kulon Progo coast is the shoreline area directly faced with the Indian Ocean. Kulon Progo generally has a sloping beach morphology, in the event of a tidal wave causing water to enter the land relatively far away so that the overflow area becomes very board and influences shoreline changes. Shoreline changes occur on a variety of scales, ranging from seconds to millions of years and vary between one place and another and are affected by several factors.
Shoreline changes occur along with the beach process due to wave activity, wind, tides, currents and sedimentation. In addition to the natural processes of the coast, changes to the coastline can also be caused due to disturbances in the coastal ecosystem such as the construction of new infrastructure around the coast so as to disrupt the existing coastal balance.

Yogyakarta Special Region (DIY) is one of the regions in Indonesia that is prone to changes in coastline. The waves height that hit the Kulon Progo coast area will be very high due to waves generating from Indian Ocean. In addition to high wave hazards, the coastal area of Kulon Progo is very vulnerable to tsunami hazards where there are encounter between Australian and Euro-Asian tectonic plates. The development of the new airport planned in the Kulon Progo area is carried out on the coastline, the planning must consider the aspects of disaster and threats from the coastal process itself. In this study, we will analyse the changes in the coastline of Kulon Progo Coast. From this research it is expected that we can find out the impact and mitigation efforts in planning new infrastructure in Kulon Progo.

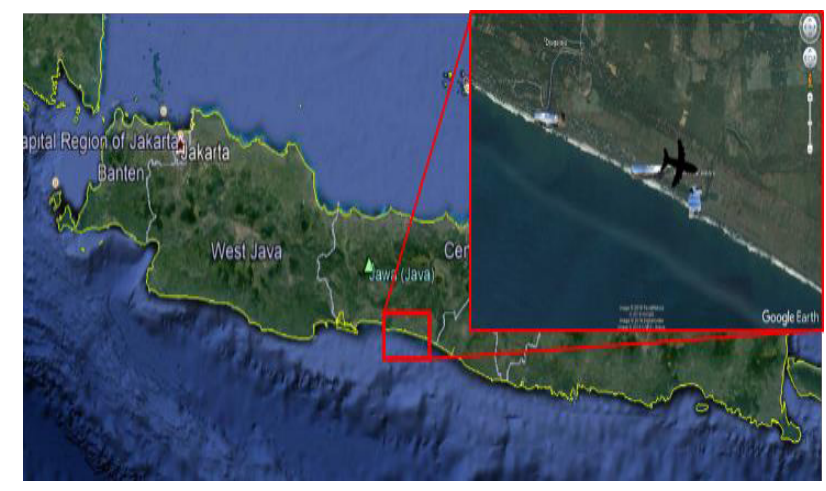

Fig. 1. Location of study

\subsection{Hydrology}

There are two major rivers at our study area, Bogowonto River on the east side of the coast and Serang River on the west side of the coast. The watersheds for both rivers can be seen in the figure 5. The Bogowonto River is seen to have a larger catchment area than Serang River catchment up to three times. Significant shoreline changes can be seen in the estuary of these two rivers. Where from year to year, river mouth morphology changes due to the high sediment transport and high wave propagation from the sea caused river mouth closure.

Serang river is seen to have built estuary protection by using a jetty on both sides of the river mouth. The effectiveness of the jetty viewed by satellite monitoring is not significant because in 2013, the sediment was still covering the estuary and caused the new river mouth formation. In the planning of coastal protection buildings, it is required a thorough analysis of the patterns of sediment movement, currents and waves. This analysis will be assisted by using numerical models to determine sediment movement patterns, so it can provide good recommendations to solving coastal problems in the coastal area of Kulon Progo. 


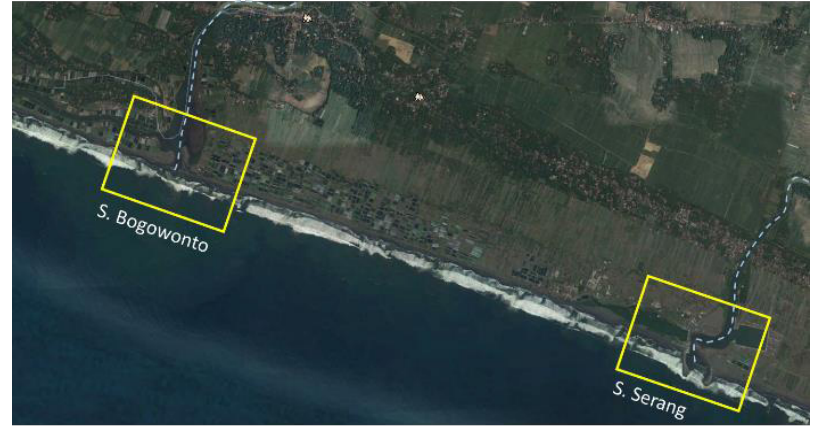

Fig. 2. River mouth location of Bogowonto and Serang Rivers

Bogowonto River with the catchment of $291 \mathrm{~km}^{2}$ has an average discharge of $20 \mathrm{~m}^{3} / \mathrm{s}$ and for Serang River with the catchment of $195 \mathrm{~km}^{2}$ has an average discharge of $9 \mathrm{~m}^{3} / \mathrm{s}$. The dependable flow of $50 \%$ and $80 \%$ can be seen on the figure 3 and 4. Dependable flow will be analyzed using F.J Mock method. F.J. Mock (1973) [12] proposed a monthly water balance simulation model for the drainage region in Indonesia, known as the Mock flow simulation. This model is specifically used for rivers in Indonesia [13]. The Mock method refers to the water balance in which the total water volume in the earth is fixed, only its circulation and distribution varies. Mock takes into account the volume of incoming (rain), out and stored water in the soil (infiltration, percolation and evapotranspiration) [14].

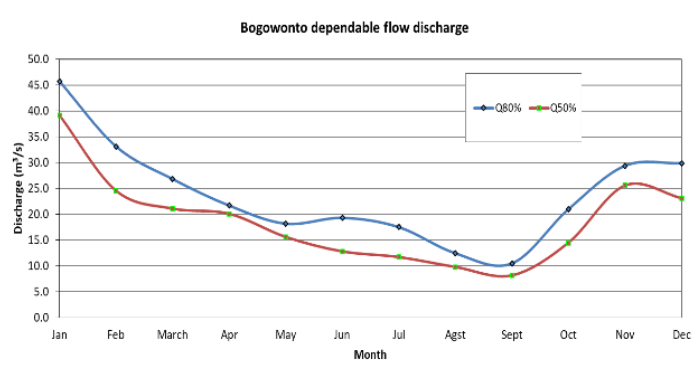

Fig. 3. Dependable flow Bogowonto river

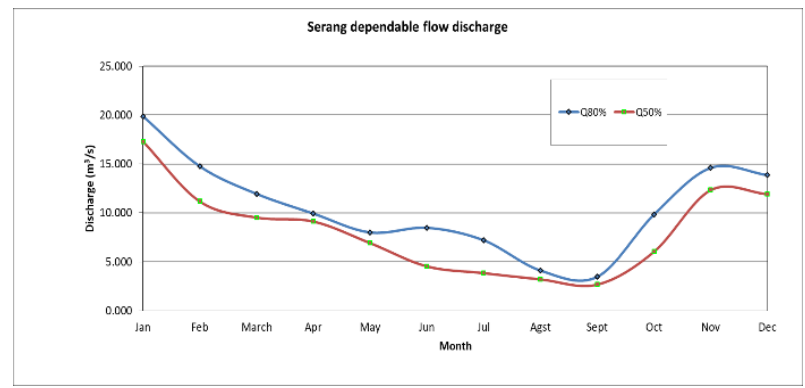

Fig. 4. Dependable flow Serang river

Peak flood discharge for these two rivers are calculated with Nakayashu method with 100-return period for Bogowonto and Serang river are $58 \mathrm{~m}^{3} / \mathrm{s}$ and $68 \mathrm{~m}^{3} / \mathrm{s}$ respectively.

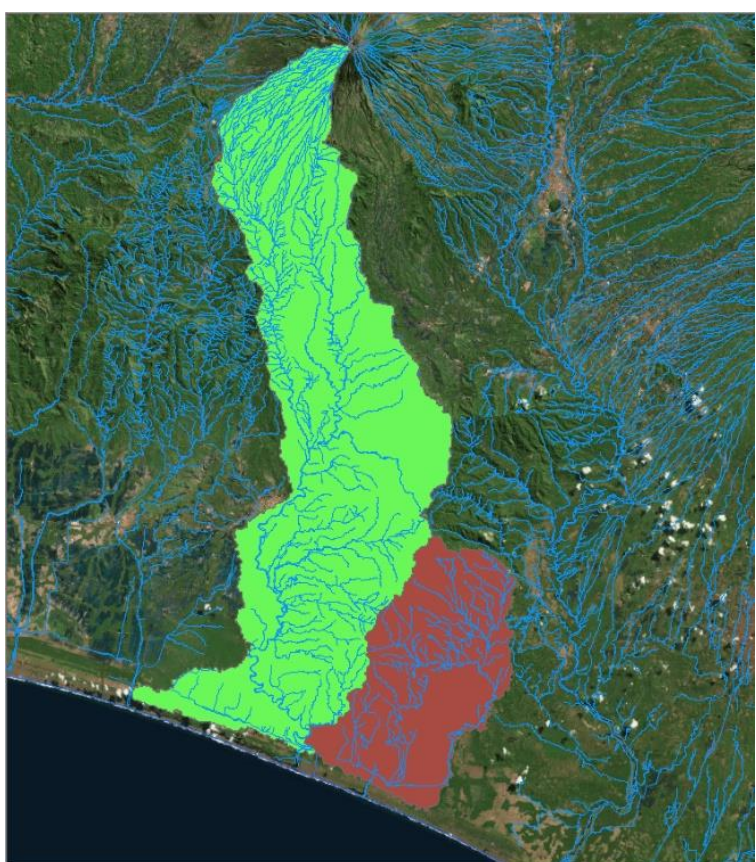

Fig. 5. Watershed of Bogowonto and Serang river

\subsection{Hydro-oceanography}

Shoreline change is considered as one of the most dynamic processes in the coastal region and is caused due to various physical and anthropogenic processes [15]. Shorelines are always subjected to change due to costal process, which are mainly controlled by wave characteristics and the resultant near-shore circulation, sediment characteristics, beach form etc [10]. In addition to hydrological aspect from land, other aspect that are related to the coastal process need to be analyze such as the tide and wave characteristic. Tide data obtain from online real-time prediction from central network of geodesy and geodynamic controls of Indonesia (tides.big.go.id). This tide prediction resulted from data assimilation of permanent tide stations and altimetry satellites.

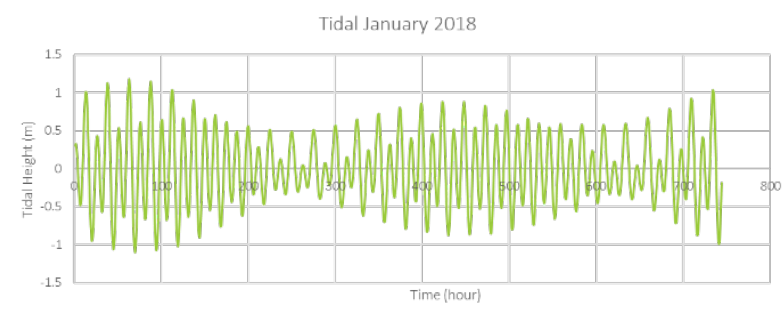

Fig. 6. Tides condition in study area

Table 1. Water level

\begin{tabular}{|l|l|l|}
\hline Higher High Water Level & 1.092 & $\mathrm{~m}$ \\
\hline Mean High Water Level & 0.8339 & $\mathrm{~m}$ \\
\hline Mean Sea Level & 0 & $\mathrm{~m}$ \\
\hline Mean Low Water Level & -0.8339 & $\mathrm{~m}$ \\
\hline Lower Low Water Level & -1.092 & $\mathrm{~m}$ \\
\hline Tidal range & 2.184 & $\mathrm{~m}$ \\
\hline
\end{tabular}


Wind data obtain for 12 years from 1 January 2006 until 31 December 2017. Data obtain from global data NOAA (National Oceanic and Atmospheric Administration) and predicted for 6 hours a day. From the wind rose generated from 12 years of data, dominant wind occurred from North-West with wind speed $5.7-8.8 \mathrm{~m} / \mathrm{s}$.

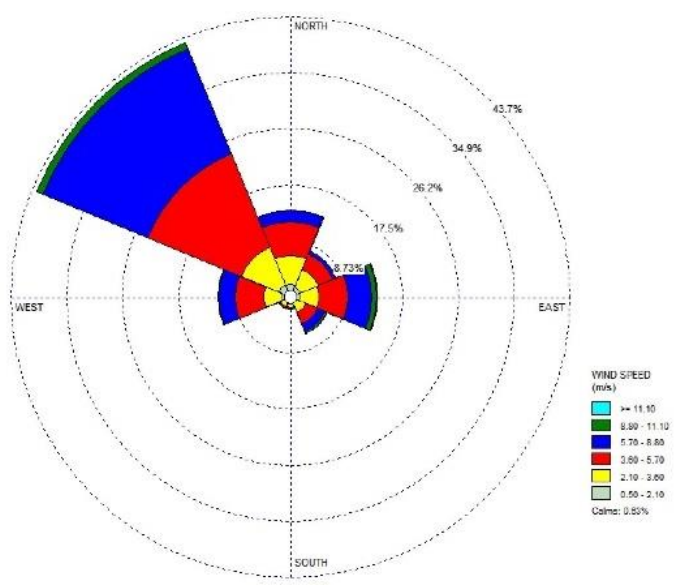

Fig. 7. Wind rose at Kulon Progo coast

From the dominant wind direction, we can see that the sediment transport tends to flow form east to the west, because wind from the east stronger ang more dominant than the wing from west. This assumption will be proven from satellite analysis at the estuary of Serang and Bogowonto River at figure 11 and 12.

Wave direction and magnitude were obtained using wave hindcasting from wind data based on SPM (Shore Protection Manual, 1984). Wave hindcasting was carried out based on wind data and the effective fetch. The results are given in wave rose as follow in figure 8 . The dominant wave direction is from the East and West. Significant wave height and period in Kulon Progo coast is $1.7 \mathrm{~m}$ with 5.7 second period.

Kulon progo coast is directly connected with Indian Ocean, this condition resulted in high wave condition from 5 to 7 meters due to the high-speed wind and huge wave generation area. The combination of small particle of sand in the Kulon Progo Coast, and high wave, strong current and sediment transport, and the sediment contribution from upstream, shoreline will keep changing from time to time.

Wave generated from NOAA data produce a dominant wave from east and west direction. However, wave rose resulting from JICA analysis in 1989 dominant wave direction is coming from South. There is a significant difference dominant wave direction from both of wave rose. These significant differences may caused by the wave generation carried out on the deep sea.

Wind prediction from BMKG also show that wind in the southern of Java flow from east to the west. Global data both the NOAA and BMKG shows similar pattern of dominant wind due to west monsoon and east monsoon and shows significant difference with the analysis from JICA. This is due to global data sense the direction of wind from the deep sea.

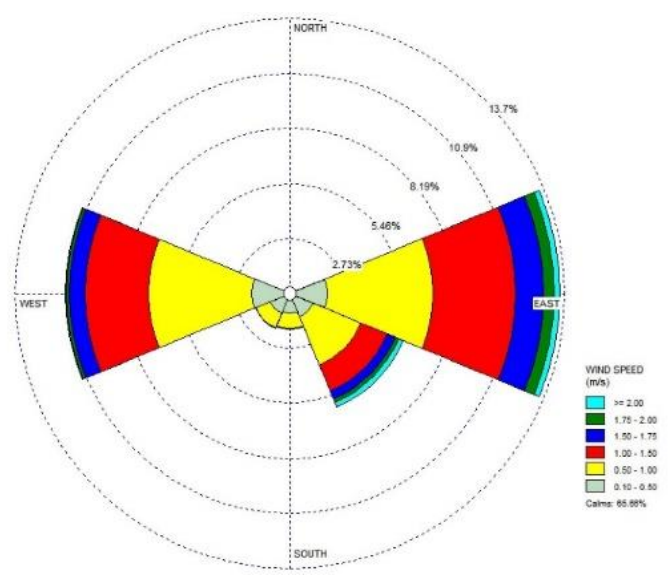

Fig. 8. Wave rose from NOAA data at Kulon Progo coast

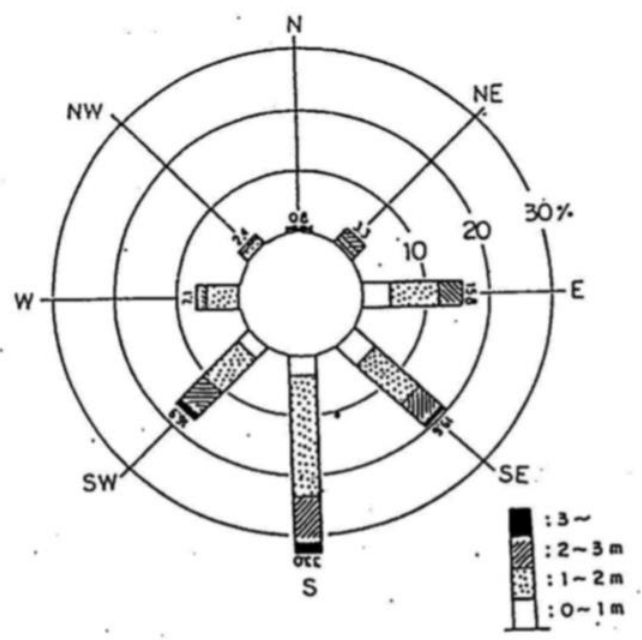

Fig. 9. Wave rose for Indian ocean, South of Bali (JICA,1989)

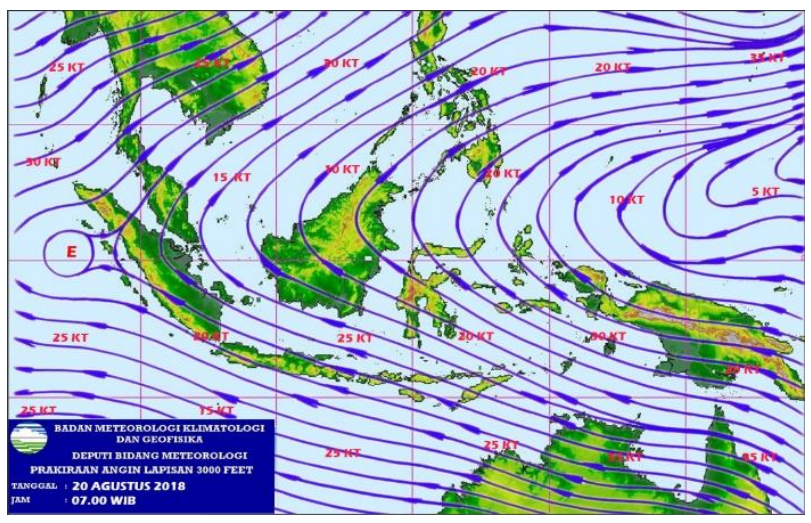

Fig. 10. Wind direction from $B M K G$

\section{Method}

There are three stages of analysis in this research, first is shoreline changes analysis from satellite images from google earth, second stages is numerical model analysis of Kulon Progo coast with secondary data, final stages will be verification of numerical model with satellite images analysis. Satellite images have been extensively used in shoreline changes detection. Satellite images were collected from Google Earth form 2002-2018 to analyzed the shoreline changes in the period of time. Beside from 
satellite images, shoreline changes analysis also conducted based on numerical simulation with Delft 3D software. Model simulation will be verified by using satellite analysis from google earth.

This process will be including the wave and current interaction to see the sediment transport along the coast. Two rivers also contribute in this model, due the discharge and sediment supply from the upstream area will contribute to the complex process of sediment transport along Kulon Progo coast.

Due to limited time and high cost for data measurement, this case will be modeled based on secondary data. The numerical analysis will be compared by the satellite analysis, and the result will be used as a recommendation to adjust the numerical model to be more accurate and reliable to predict the sedimentation and accretion process in long-term period to conduct future prediction of shoreline position.

\section{Result and discussion}

Changes of shoreline through process of accretion and erosion can be analyzed in geographic information system (GIS) by measuring the differences in past and present shoreline locations. The source for this analysis will be using satellite photo from google earth from year 2002 to 2018. This short-term period analysis in due to lack of time series data from the resources. Several studies using satellite data have proven its efficiency in understanding various coastal process $[16,17,5,6,7]$. Short-term period analysis will be beneficial for setting up a long-term programme to provide the systematic information on coastal process of sedimentation and accretion in Kulon Progo coastal zone management.
These findings also beneficial on determining the mitigation strategy for disaster hazard especially to the new development of coastal infrastructure. From satellite images, we monitored the development of Kulon Progo coastline during 16 years (2002-2018). In this period, the coastline shifting up to $60 \mathrm{~m}$. Satellite analysis is corresponding with the previous study where they conduct a survey by interviewing local people and gave a testimony where the previous Bugel beach has a length of 100 meters and now only 40 meters due to the abrasion [18].

The greatest impact of sedimentation and abrasion in this coastline can be seen in estuary of Bogowonto and Serang river. Detailed time-series satellite photo of each river can be seen in figure 11 and 12 . we can observe that the morphology of the mouth of the estuary always changes significantly, the sedimentation transport tends to flow from the east and begins to cover the mouth of the estuary. Due to the large waves from the deep sea, the sand spits that cover the estuary will be pushed into the estuary and the sediment will form the island or a pile of sediment inside the estuary. Previous study conducted on Kuwaru coastline, Bantul Region, Province of Yogyakarta, analyze coastline change under wave attack. The study concluded that the erosion in Kuwaru beach happen due to the variation of wave steepness and lack of sediment supply from the river during dry season. The Kuwaru coastline shifted around 50 meters during 10 years (2008-2017). To reduce the risk of coastal disaster, especially against wave attack and erosion, the minimum width of Kuwaru setback zone should be 120 m [19].

Similar process also analyze in previous study in Cilacap, the estuary of Serayu River. The result shows from a simulation that the east side of estuary moves as far as 40 meters. The spits grow very rapidly and causes threat to the existence of the cutoff [20]. Others study also

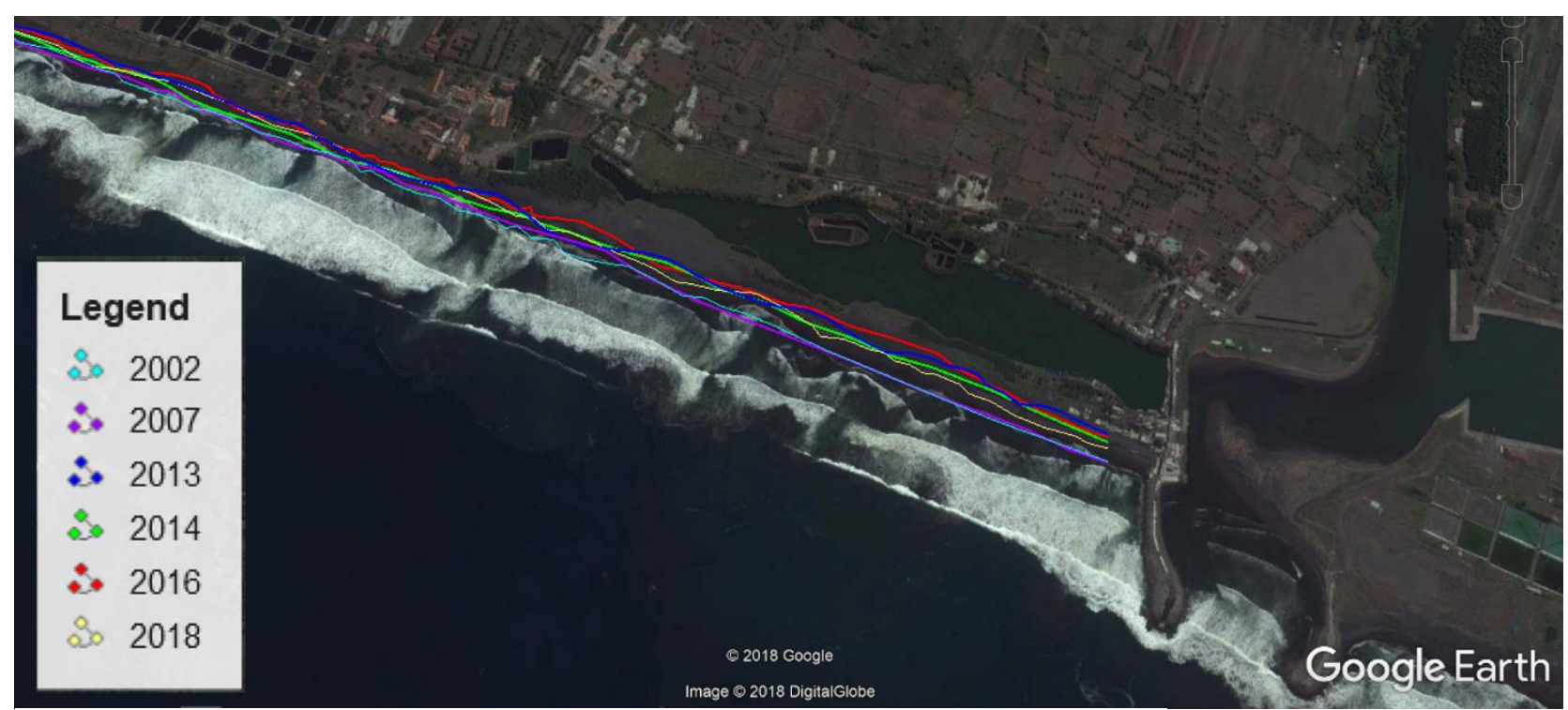

Fig. 10. Shoreline changes from satellite (Google earth) 


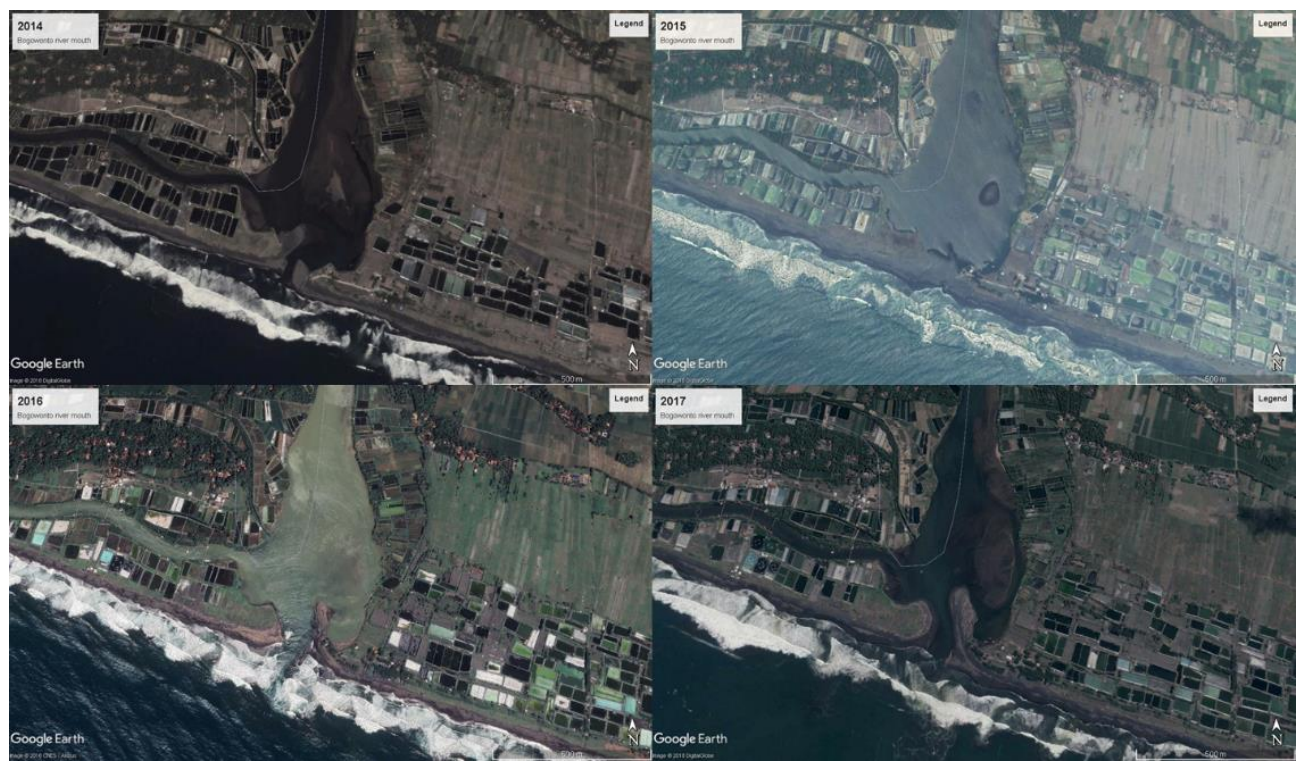

Fig. 11. Satellite photo of Bogowonto river mouth morphological changes (Google Earth)

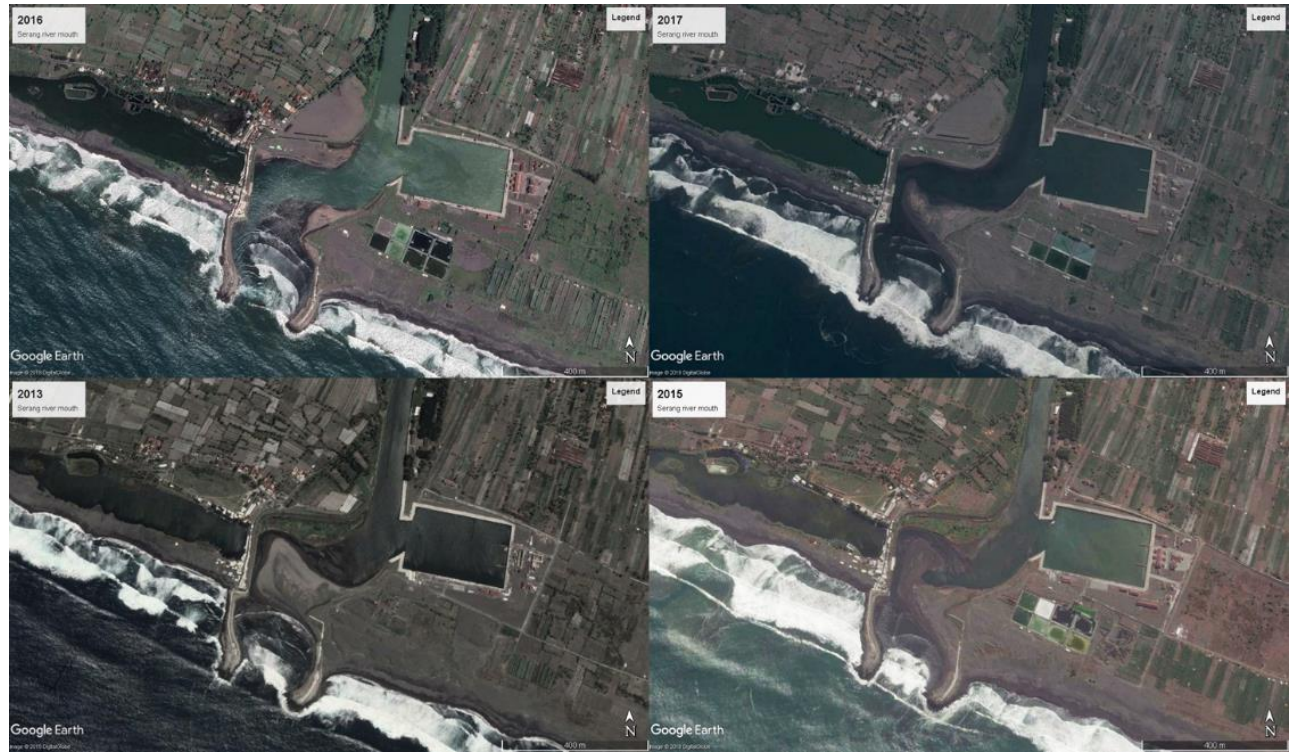

Fig. 12. Satellite photo of Serang river mouth morphological changes (Google Earth)

mention that the net sediment transport flows to west direction with $293.000 \mathrm{~m}^{3} /$ tahun. This phenomenon caused the sediment to pile on the east side of the jetty at Tanjung Adikarto fish port [21]. Tanjung Adikarto fish post is still not operating until now, because of high sedimentation at the cruise line. The design is not in accordance with the coastal process especially for Southern Java coast which is faced directly with the Indian Ocean. Most of the port in southern java build coastal protection from high wave from the South and also sedimentation transport from east and west area. Tanjung Adikarto not consider the effect from high wave from South, so that sand spit grows inside the cruise line and result in silting. This case is becoming the example of how important is understanding coastal process and shoreline changes to know the right solution for coastal problem. Coastal infrastructure development that is not suitable, will change the equilibrium of the coast and cause the coastline to change continuously. Numerical model also conducted in this research with Delft 3D software. The simulation modeled for ten years, to know the sediment transport pattern in Kulon Progo coast. This simulation used secondary data for boundary condition, and bathymetry. The simulation will used flow simulation model by analyzing the process of tidal, discharges and wave interactions. Boundary condition in this research already describe at section two, with tidal and significant wave for open boundary and average flow for river discharge. The numerical model shows that the erosion and sedimentation occurred along the Kulon Progo coast due to the strong current especially between the two main rivers. We can observe in figure 13 (b), erosion occurred up to 2 meters along the coast and change the shoreline to set back up to 190 meters. This value is much higher compare to the previous analysis and satellite analysis with 60 meters shoreline set back. The sedimentation pattern from numerical model is in accordance with the satellite analysis. Heavy erosion in coastal zone without treated properly will become a serious damage to the infrastructure around coastal area. The infrastructure 


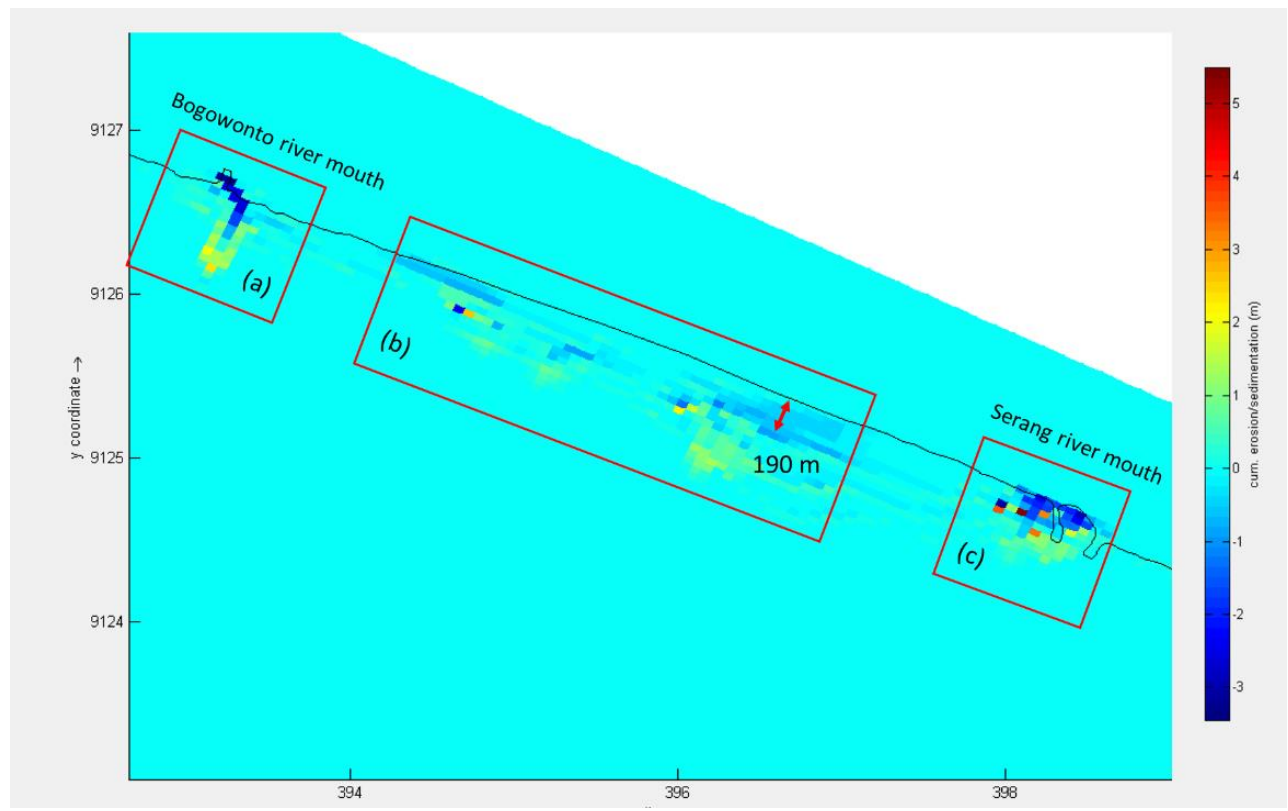

Fig. 13. Numerical model of Kulon Progo shoreline changes

planning needs to be considered the heavy erosion in Kulon Progo coast, with structural protection or determining appropriate coastal set-back.

Figure 13 (a) and (b) shows a high sedimentation rate at the river mouth of both rivers. High sedimentation rate can cause the possibility of silting in estuary. The silting can inhibit river flow to the sea, if the sedimentation keeps increasing in can leads to closure of estuary. The river flow will divert to a new river moth and change the river morphology just like Bogowonto rivers from satellite analysis at figure 11 . The silting in estuary already happened frequently in Bogowonto rivers as we can see in figure 14, especially in dry season. High sedimentation rate and minimum flow rates from rivers resulting in sediment cannot be transported along the coast and deposit around the river mouth. The sediment transport process in general cannot be described well on this numerical model. Thus, a field data survey is needed so that the model can represent the field conditions well and have a better and more reliable model result.

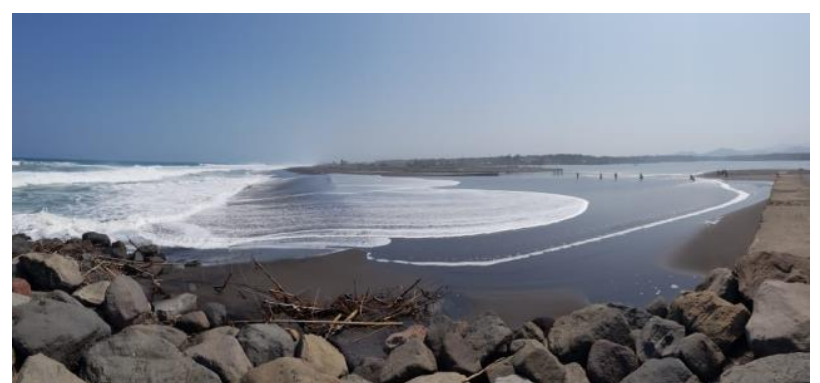

Fig. 14. Silting in Bogowonto rivers in dry season

\section{Conclusion}

The satellite photos along the Kulon Progo coast was analyse for 16 years from 2002 to 2018. From satellite images, huge abrasion occurred up to 60 meters. Numerical models also show similar pattern of heavy erosion around Kulon Progo Coast. Numerical models show erosion occurred up to 2 meters and coastal set back up to 190 meters. This simulation is not accurate; thus a field data survey is needed so we can have more reliable result. This abrasion caused by huge wave attack from the Indian Ocean and lack of sediment supply especially in dry season. Strong current from south east to north west also caused a sedimentation on the east side of the infrastructure along the coast and abrasion on the west side. From satellite analysis in Serang and Bogowonto rivers we can observe the sedimentation transport and high sediment rate especially in estuary. High sedimentation in estuary can cause silting and river mouth closure, this event has happened frequently especially in dry season when the flow rate decrease.

Shoreline retreat is a threat in the region and may affect the NYIA development greatly. It is proposed that in order to reduce the risk of coastal disaster infrastructure development near the coastline is not recommended. Coastal protection using mangroves is not recommended in the Kulon Progo beach area due to high waves, structural protection is recommended specially to protect infrastructure from disaster hazards and natural coastal process.

This research is supported by the Program Penelitian, Pengabdian kepada Masyarakat, dan Inovasi (P3MI), Institut Teknologi Bandung

\section{References}

1. M. B. Adityawan, H. Tanaka, and H. Nagabayashi, Investigation of Shoreline Change Caused by The Great East Japan Tsunami 2011 Around Samegawa River Mouth. Proceedings of Coastal Engineering, JSCE, Vol.3, 2012, November (2012)

2. H.Tanaka, M. B. Adityawan, A. Mano, Morphological Changes at the Nakita River Mouth after the Great East. (2014). Coastal Engineering, 86 (2014) 14-26 
3. M. B. Adityawan, H. Tanaka, and H. Nagabayashi, Assessment of The Morphological Changes at The Samegawa River Mouth, Japan, Proceedings of The $12^{\text {th }}$ International Symposium on River Sedimentation (2013)

4. M. B. Adityawan, N. X. Dao, H. Tanaka, A. Mano and K. Udo. (2014). Coastal Engineering Journal.

5. V. Makota, R. Sallema, C. Mahika, Monitoring shoreline change using remote sensing and GIS: A case study of Kunduchi Area, Tanzania Western Indian Ocean J. Mar. Science, 3(1): 1-10 (2004)

6. M. Murali, D. Shrivastava, P. Vethamony, Monitoring shoreline environment of Paradip, East coast of India using remote sensing, Current Science, 97(1): 79-84 (2009)

7. M. Boutiba, S. Bouakline, Monitoring shoreline changes using digital aerial photographs, quick-bird image and DGPS topographic survey: Case of the east coast of Algiers, Algeria. European Journal of Scientific Research, 48(3): 361-369 (2011)

8. M. Sheik, A shoreline change analysis along the coast between Kanyakumari and Tuticorin, India, using digital shoreline analysis system. Geo-spatial Information Science. pp 282-293 https://link.springer.com/article/10.1007/s11806011-0551-7 (2011)

9. T. I. Maryanto, W. Windupranata, S. Bachri. Studi Perubahan Garis Pantai Berdasarkan Interpretasi Citra Satelit Landsat dan Perhitungan Rasio Lahan di Wilayah Pesisir Indramayu Jawa Barat. Jurnal Rekayasa Hijau. Vol.1. (2017)

10. A. Kumar, A.C. Narayana, K.S. Jayappa, A Shoreline changes and morphology of spits along southern Karnataka, west coast of India: A remote sensing and statistics-based approach. Geomorphology 120 (3-4), 133-152 (2010)

11. G. Vivek, Shoreline change analysis for North East Coast of Andhra Pradesh, India. Conference: ISPRS WG VIII/1 Workshop on Geospatial Technology for Disaster Risk Reduction at: Jaipur, IndiaVolume: Commission VIII, WG VIII/1. DOI: 10.13140/RG.2.2.19763.73767 (2015)

12. F.J. Mock, Water Availibity Appraisal (1973)

13. Badan Perencanaan Pembangunan Nasional, Identification of Java Island Water Resources Management Problem. Water Resources Management on Resolving Drought and Flood Initiative Strategies. Book 2, Final Report (2006)

14. Y. Suryadi, A. Chrysanti, Study on Water Resources Allocation for Kertajati, Jatitujuh, and Ligung SubDistricts to Support the Development of West Java International Airport (BJIB) and Kertajati Aerocity Area. SIBE (2017)

15. S. Chen, L. Chen, Q. Liu, X. Li, Q. Tan, Remote sensing and GIS based integrated analysis of coastal changes and their environmental impacts in Lingding Bay, Pearl River Estuary, South China. Ocean \&Coastal Management 48, 65-83 (2005)

16. W. Ahmed, D. T. Neil An evaluation of landsat thematic mapper digital data for discriminating coral reefzonation, heron reef (GPR). International Journal of Remote Sensing, 15: 2583-2597 (1994)
17. K. Anbarasu, R. Baskaran, G. V. Rajamanickam, Influence of sea level changes in the development of landforms around Chidambaram, Tamilnadu. Indian Journal of Geomorphology, 4(1\&2): 13-18 (1999)

18. H. Cahyono, T. Retno, W. Musrifah, E. Maulana, Analisis Perubahan Garis Pantai dengan Menggunakan Data Citra Landsat di Pesisir Kabupaten Kulonprog. Parangtritis Geomaritime Science Park (2017)

19. N. Yuwono, D. T. Thy, Kuwaru Coast Line Changing Under Wave Attack. The $12^{\text {nd }}$ SEATUC Symposium (2018)

20. B.K. Hanh Tuah S. Syahril, Nazili. (2006) Mathematical Model of Spit Growth in Serayu Estuary, Central Java, Indonesia. Proceedings of the Sixteenth (2006) International Offshore and Polar Engineering Conference

21. N. Yuwono, Potensi Revitalisasi Pelabuhan Adikarto (2017)

22. T. W. Wagner, J. L. Michalek, R. Laurin, Remote Sensing application in the coastal zone: a case from the Dominician Repulic [R], Consortium fir International Earth Science Information Network Report, University Center, Michigan (1991) 